\title{
RISK ACCEPTATION PRINCIPLES IN TRANSPORT
}

\section{ZASADY AKCEPTOWALNOŚCI RYZYKA W TRANSPORCIE}

\author{
Andrzej Szymanek \\ Technical University of Radom. Faculty of Transport \\ Politechnika Radomska. Wydzial Transportu \\ 26-600 Radom, ul. Malczewskiego 29 \\ a.szymanek@pr.radom.pl
}

\begin{abstract}
In this paper are presented few methodological problems related to valuing and acceptation risk in transport. In this lecture are presented such problems as: 1. philosophical, ethical and practical rules of risk acceptation. 2. ALARP, ALARA, GAMAB, MEM principles in relation to risk in transport.
\end{abstract}

Keywords: transport, risk acceptation, risk management, safety transport

Streszczenie: W artykule przedstawiono kilka problemów metodologicznych dotyczących wartościowania $\mathrm{i}$ akceptacji ryzyka $\mathrm{w}$ transporcie. $\mathrm{W}$ pracy przedstawiono $\mathrm{m}$. innymi takie problemy, jak: 1 . filozoficzno-etyczne i praktyczne zasady akceptacji ryzyka. 2. zasady ALARP, ALARA, GAMAB, MEM w odniesieniu do ryzyka w transporcie.

Slowa kluczowe: transport, akceptowalność ryzyka, zarządzanie ryzykiem, bezpieczeństwo transportu 


\section{RISK ACCEPTATION PRINCIPLES IN TRANSPORT}

\section{Introduction}

Safety transport management is managing by purposes, what means some type of system management. Aims of safety management in any transport system can be defined in according to "defence-in-depth-philosophy" conception:

1. accidents risk minimizing (prevention),

2. number of accidents minimizing (active safety methods),

3. accidents effects minimizing (passive safety methods),

4. transport accidents effects minimizing (evacuation plans, crisis management).

Safety management in transport is implied in operation sense as risk management. This is an approach of "ex ante" type to problem of safety improvement. It relies on proactive idea of "anticipation", avoidance or notable reduction of expected accidents effects. Meanwhile tradition "ex post" approach is a reactive conception of inferring from postaccidents information.

\section{Risk in transport}

In relation to transport we can talk about "multidimentional" risk. It has connection with transport elements (transport infrastructure, means of transport, human), but also with realization of supply chain, and in such sense we can talk also about logistics risk, [1]. Reduction of "multidimensional" transport risk can be reached by risk management; "measuring risk to manage it" - this phrase shows the essence of the risk management also in transport.

Risk management creates three areas of risk research:

1. risk analysis - threats identification and estimating the frequency of its (threats) occurring and also risk estimation;

2. risk evaluation - determining accepted risk levels;

3. risk control - reaching accepted risk level by existing economical and social restrictions.

Each stage of risk management has rich literature which is placed in the lecture [2]. 
At risk evaluation stage the key issue is choice of risk evaluation criterion. Such criterion always relates to difficult problem of social risk acceptance, [3].

So far there is no criteria of risk evaluation which are specific for transport systems. Common criteria are applied, which implementation and also quantification (risk acceptance levels) in relation to transport is raised in this lecture.

\section{Risk valuation and acceptance}

Risk valuation and acceptance problem is universal, both in individual dimension and social dimension. Development of new technologies generate new risks, what can imply new forms to its acceptation. Risk acceptance should have some points of reference: the easiest way is relating to acquired experience and existing rules and norms. But new risks give new experiences, what should influence on rights changes and so far obliging norms, [4].

Below there are three (there is more) practical risk acceptance rules, which can be related to transport:

1. in case of apperance the risk of serious transport accidents, it is aimed to keep safety level not worse than in other countries; "daily risk" should not considerably increase as a result of human participation in transport activity (e.g. taking part in road traffic);

2. by planning transport investment, the researches should be carried on, if there are alternatives, thanks to which the similar transport effect will be gained by lower risk;

3. means to improve transport safety should be located where they give the best results.

From known in industry "practical rules" of risk valuation there are:

1. experience - used for risk valuation in repetitive situations and conditions;

2. norms - its importance is considered in each risk acceptance procedure;

3. deep defence - according to this rule none mean of transport is perfect, and because of that it's needful to use several safety measures (barriers, layers) for each potential accident in analysed technology system;

4. quantity risk analysis - rule of operation approach to risk evaluation;

5. Risk Cost Benefit Analysis, (RCBA) - rule which considers "risk" for economical category. 


\section{Criteria of valuation and risk acceptance; Implementation to transport}

In risk valuation there are used two basic methods: 1 . comperative method, 2. substitution method. Comperative method consists in comparing calculated risk with known and accepted individual and group risk or risk level of natural threats. Risk field is divided into three levels:

1. accepted risk (set by state authority in safety policy framework),

2. tolerated risk,

3. non-accepted risk.

Choice of risk is made between: "broadle accceptable level of risk" and "non-accepted risk level", which should not be exceeded (irrespective of expected economic or social benefits). Between those two border risk there is "tolerated risk field". And in relation to "tolerated risk" different criteria (rules) of risk choice are used.

ALARP (As Low As Reasonably Practicale) is introduced by Health and Safety Executive, [5]. According to that rule - the best is choice such risk which is "as low as it is practical justified".

In relation to analysed part of any transport system - interpretation of ALARP rule would be as follows: technical condition of mean of transport, element of transport infrastructure, operating process (activity) - are considered as much safe as calculated risk for them is "as low as it is practical justified". Risk control depends on keeping residual risk at accepted risk level, which can be determined by methods of preference researches by using expert technologies, or determined by RCBA, [6].

In most European countries maximum accepted individual risk is $10^{-6} /$ year, while group risk is $10^{-5}$ /year or even $10^{-4} /$ year (Denmark), [7].

ALARP criterion was used among the others in railway transport in Great Britain and in road and railway transport in Switzerland. At british railways are used the following criterial values, [8]:

1. upper level of ALARP field: individual risk of railway workers $-10^{-3}$, passengers and public $-10^{-4}$ [death/year];

2. lower level of ALARP field: individual risk of workers, passengers and public $-10^{-6}$ [death/year].

ALARP rule was used also in risk management of sea transport. Especially was used in Formal Safety Assessment methodology, [9].

In Netherlands tolerated risk field is divided into two fields and individual risk has to be reduced to $10^{-6} /$ year at rate which depends on technic and technology progress. The ALARA (As Low As Reasonably Achievable) 
rule which is used here is fully justified. This rule was used also in road transport, [10].

One of main purposes of safety transport prevention is minimizing extra social (group) risk which is an effect of transport system exploitation; it is important that it will not exceed the absolute value of basic risk $\mathrm{R}_{\mathrm{ag}}$. To guarantee that, the Annual Mean Risk Distribution Function, AMRDF should be determined. AMRDF shows on what risk is exposed each person of tested group and which risk is bigger and smaller than absolute value $\mathrm{R}_{\mathrm{ag}}$, [11]. AMRDF function can be used in taking a decision regarding ways of transport and route options - in dangerous goods transport, both in road transport and railway transport.

From many well known risk aceptance values in transport risk analysis practical application can find among the others: Fatal Accident Rate (FAR) and Potential Loss of Life (PLL).

French rule GAMAB - Globalement Au Moins Aussi Bon or in english Globally As Good As Exiting is shortly expressed: safety is comparable to the equivalent system. Regarding to this criterion a new transport system can not give bigger risk than technical and exploitative risk of existing equivalent transport systems. This criterion is imprecise just as ALARP, [12]. The above rule sometimes is presented as $\boldsymbol{G A M E}$ - Globalement $\boldsymbol{A} \boldsymbol{u}$ Moins Equivalente. It tells that each change in system must leave it at least as safe as previously. The rule provides formally actual safety level as a point of reference and makes it an absolute criterion. At least three European Union countries are using this criterion to estimating and determining purposes in safety transport programs, [13].

And here it is an example of using the GAMAB criterion in analyse of new investment risk in railway transport, [14]. The thing is that proportion of railway fatalities in old and new sytem would be constant:

$$
\frac{n_{C}}{r \times C}=\text { const }
$$

$n_{C}-$ number of casualties per collision in this new system; $r$ - mean occupation coefficient (train not completely full); $C$ - capacity of one train (passenger/train).

German rule MEM - Minimum Endogenous Mortality can be shortly expressed: perceived to be acceptable by the society. New technology introduced "here and now" can not "meaningly" raises mortality of any social group. It means that new technology can not cause risk which takes effect of bigger mortality than "mortality of reference", that is natural 
mortality recorded in age group 5-15 years old. The point of reference can be here written in CENELEC pre-standard prEN 50126 - level of mortality is about $2 \times 10^{-4}$ to $10^{-5}$ people per year.

MEM criterion means that individual acceptable death risk should be lower than some predetermined limit. In case of increasing risk as a result of new technical installation (e.g. new transport investment) individual acceptable death risk can be inversely proportional reduced to number of endangered people, Fig.1. It seems that this risk value can be especially used in risk analysis of especially dangerous goods transport.

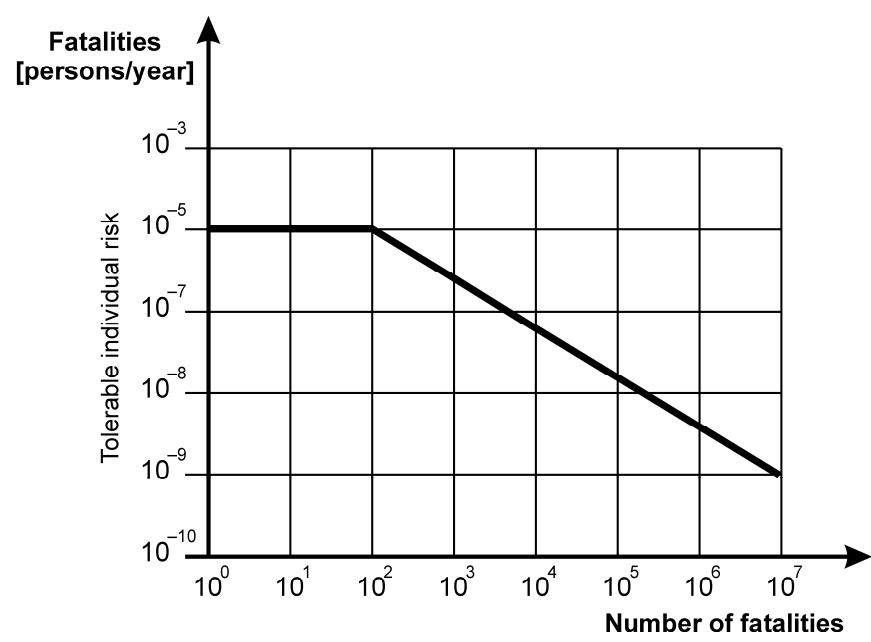

Fig. 1. MEM principle - individual acceptable death risk dependent on expected number of death, [11, p. 427]

As an example of using the MEM criterion to risk evaluation in railway transport (for british and german railways) we present socalled tolerated (socialy accepted) risk level $T$, which is a function of:

1. average number of victims of accidents which fall on one railway accident, $C / A$;

2. average number of accidents which fall on statistical journey, $A / J$;

3. distribution of number of railway accidents in time, $d A / d t$;

4. differential risk aversion factor, $f(C)$;

5. factor $b$ describes the benefit provident by the rail transport system.

Then risk tolerability $\mathrm{T}$ can be defined as follows, [9]:

Because high level of $T$ meets low risk level $r$ (and vice versa) we can conventionally write a formula of accepted railway transport risk level; 
the formula can be transferred from railway transport to another way of transport. Then another interpretation of "journey" term is necessary.

$$
r=\frac{1}{T}=\frac{\frac{C}{J} \times \frac{d A}{d t} \times f(C)}{b}
$$

\section{Problems of risk valuation in road traffic}

In risk valuation of death in road traffic the MEM criterion was used; calculated indicator $10^{-4}$ per person $x$ year based on following data: 1 . total number of accidents during the year; 2. total number of vehicles in traffic; 3 . average annual mobility - average annual number of driven kilometers, [15].

In comparison with MEM criteria, that is $2 \times 10^{-4}$ fatalities/person/year, it is similar risk level; to remind - MEM criterion relates to mortality in age group of 5-15 years old and suppose that man is exposed to activity of 20 different technical installations. Accepted risk by MEM is $10^{-6}$ per person $x$ year, that is $10^{-10}$ per person $x$ hour. If that indicator would be related to one vehicle then it would be $10^{-7}$ per vehicle.

GAMAB, ALARP and MEM rules was used in creating methodology of safe valuation - Advanced Vehicle Control and Safety Systems, that is systems which are used to avoiding collisions in vehicular traffic, [16].

In transport risk analysis the formula: $\boldsymbol{P R}=\boldsymbol{M} \boldsymbol{x} \boldsymbol{T R}$ is used; where: $\boldsymbol{P R}-$ personal risk - death risk in road accident related to number of road traffic participants; $\boldsymbol{M}$ - motorization - number of vehicles; $\boldsymbol{T R}$ - traffic risk death risk in road accidents related to some measure of risk exposition, e.g. number of vehicles-kilometres.

The basic model of safe quantification in road traffic is following, [17]:

$\boldsymbol{I}=\boldsymbol{E} \times \boldsymbol{A} / \boldsymbol{E} \times \boldsymbol{I} / \boldsymbol{A}$; where: $\boldsymbol{I}$ - number of people injured; $\boldsymbol{E}$ - exposure risk; $\boldsymbol{A} / \boldsymbol{E}$ - the probability of an accident (accident risk); $\boldsymbol{I} / \boldsymbol{A}$ - the probability of being injured in an accident (injury risk).

The above model implied means of safe improvement: all should minimize parameters: $\boldsymbol{A} / \boldsymbol{E}, \boldsymbol{E}$ and $\boldsymbol{I} / \boldsymbol{A}$.

And here it is an illustration of $\boldsymbol{E}$ parameter influence on risk level of mortal transport accidents. 
Table 1. Fatality risks over distance and time for travel models in the EU.

Source: ETSC (1999)

\begin{tabular}{|c|c|c|}
\hline Travel mode & $10^{8}$ person-km & $10^{8}$ person-hours \\
\hline ROAD & 1.1 & 3.3 \\
\hline TRAINS & 0.04 & 2 \\
\hline FERRIES & 0.33 & 10.5 \\
\hline PLANES & 0.08 & 36.5 \\
\hline
\end{tabular}

It is worth to mention that number of road accident is an increasing function of E exposition. In literature the function is called: Safety Performance Function, $S P F$, [18]. Mostly E parameter is expressed as an intensity of road traffic or number of driven kilometeres. SPF is often non-linear. The below figure shows an exemplary shape of SPF function for determined road.

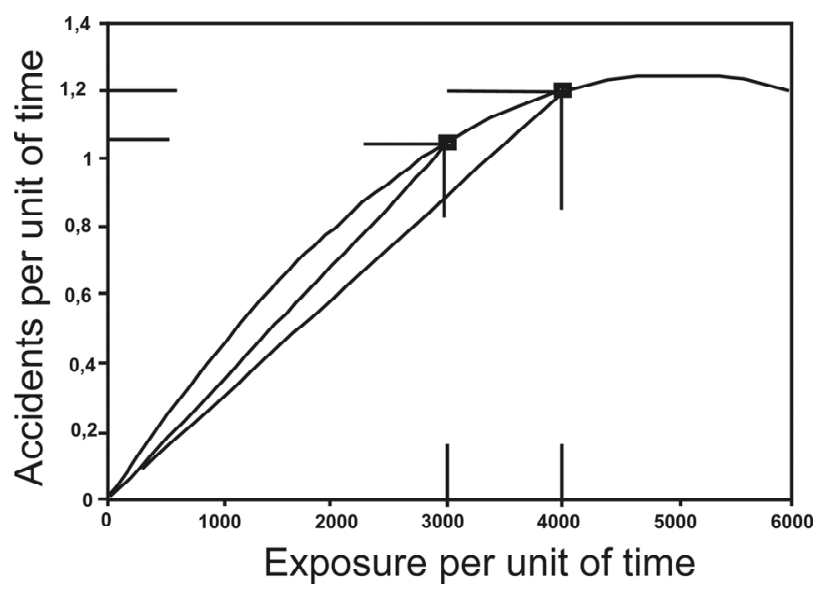

Fig. 2. Safety performance function and accident rate, [18]

There is another indicator of risk in road traffic. There is a simple definitional relationship between health risk and traffic risk, [19]:

$$
H R=T R x M R
$$

$\boldsymbol{H R}$ - health risk (killed per 100.000 inhabitans)

$\boldsymbol{T R}$ - traffic risk (killed per 100.000 motor vehicles)

$\boldsymbol{M R}$ - motorisation risk (the number of motor vehicles per inhabitant in a country). 
Table 3. HR and TR values for several countries. Source: WHO Regional Office for Europe, Copenhagen 2005

\begin{tabular}{|l|c|c|}
\hline \multicolumn{1}{|c|}{ Country } & HR & TR \\
\hline Australia & 9.5 & 15.3 \\
\hline Poland & 16.3 & 44.6 \\
\hline United Kingdom & 6.0 & 12.1 \\
\hline United States & 15.2 & 19.3 \\
\hline Total IRTAD & 12.2 & 20.6 \\
\hline
\end{tabular}

And here are estimations of European Road Safety Mortality Rate, ERSMR, come out of road accidents statictics from $2000-2005$ years:

ERSMR $=40.000 / 375 \times 10^{6}=1.07 \times 10^{-4} / \mathrm{a} ;$ ERSMR $_{\mathrm{TF}}=5 \times 10^{-6} / \mathrm{a}$; $E_{R S M R}{ }_{H F}=1 \times 10^{-4} / \mathrm{a}$; where: ERSMR $\mathrm{TF}_{\mathrm{TF}}=\mathrm{ERSMR}$ for Technical Failure; $E_{R S M R}=$ ERSMR for Human Failure.

Using known criteria of risk valuation and accepting determined by European Comission level of 20.000 road fatalities in 2010 year, [20] - we can determine:

$$
\text { Accepted European Road Safety Mortality Rate }=5.3 \times 10^{-5} / \text { a }
$$

where: $5.3 \times 10-5 / \mathrm{a}=20.000 / 375 \times 10^{6}$; here the number $375.000 .000-$ it is a number of drivers of vehicles at European Union area. So the value $5.3 \mathrm{x}$ $10^{-5} / \mathrm{a}$ can be considered as an accepted level of road risk in UE in 2010 year.

Risk Homeostasis Theory, RHT. According to RHT conception behaviour of each traffic road participant in determined road situations is adequate to "accepted risk level"; it means it is a resultant between accepted risk (subjective) and real risk (objective). In RHT there are defined loses in accident as product of accidents frequency and costs of them (accidents). From this it follows that change of safe level depends on objective accident probability and on estimated costs of accident. Then it can be that improvement can be a result of accident costs reduction, even though objective probability of accidents is the same. Algebraical RHT formula of theory is follow: $\boldsymbol{F}=\boldsymbol{T} \boldsymbol{x} \boldsymbol{R}$. Number of road fatalities $\boldsymbol{F}$ is directly proportional to total time $\boldsymbol{T}$ of participation in road traffic and to statistical average level of risk $\boldsymbol{R}$, which is accepted by participants of road traffic. The formula is used for selected area of roads; the thing is estimating number of participants $P$ in road traffic. 


\section{Summary}

What is acceptable risk level then? The unequivocal answer is impossible. Each risk level which is different than zero is arbitrary and controversial. Besides talking about acceptable risk level there should be made a distinction between different kind of risks: individual, social, voluntary, etc. What risk level is acceptable for individual transport user, when he/she is in journey to determined destination and travel by determined mean of transport? What is acceptable risk for society as unity, it means how many accidents or injured people in year scale - society can accept in transport systems? These are basic questions and there are more.

Problem of risk valuation in different transport systems is here a key problem.

\section{References}

1. Szymanek A., Road safety transport: some methodological reflection's. 10th International Conference "Computer Systems Aided Science, Industry and Transport" TRANSCOMP 2006, Vol. II, p. 361 - 366. Zakopane, 4 - 7 December 2006

2. Szymanek A., Bezpieczeństwo i ryzyko w technice. Politechnika Radomska. Radom 2006, sec. V

3. Jennergren L. P., Keeney R. L., Metody oceny ryzyka. (w:) Analiza systemowa - podstawy i metodologia. W. Findeisen (red.), PWN, Warszawa, 1985 s. 572

4. Ashby F. R. S. The Risk Equations: The Subjective Side of Assessing Risks. New Scientist 1977, vol.74, No. 1052, s. 398-400

5. The Tolerability of Risk from Nuclear power Stations. HSE. London 1992.

6. Prest A. R.,Turvey R., Cost-Benefit Analysis: A Survey. Economic Journal 1965,vol. 75, s. 683-735

7. A review of risk control. SVS 1994/27A, VROM, 1995

8. Brearly S. A., UK Railways: Using Risk Information in Safety Decision Making. Proceedings of Workshop on Promotion of Technical Harmonization on Risk-Based Decision-Making. Stresa 2000

9. Ch. A., Kontovas, Formal Safety Assessment. Critical Review and Future Role. /Diploma Thesis, July 2005/. National Technical University of Athens. School of Naval Architecture \& Marine Engineering

10. Khalil J. Spencer, Traffic Safety: An integrated ALARA approach; (http://www.bikewalk.org) 
11. Kuhlmann A., Introduction to Safety Science. New York - Berlin Heidelberg - Tokyo, 1985, s. 430

12. A discussion of Risk Tolerance Principles. /By Odd Nordland - wg: http://www.informatics.sintef.no

13. Assessing Risk and Setting Targets in Transport Safety Programmes. ETSC Report, Brussels 2003

14. CENELEC prR009-004, "Railway applications, Systematic Allocation of Safety Integrity Requirements", March 1999

15. The Netherlands Derivation of Safety Targets for the Random Failure of Programmable Vehicle Based System. SafeComp 2000, 25-27 October 2000, Rotterdam

16. E.M.El Koursi, Ching-Yao Chan and Wei-bin Hang, Preliminary Hazard analnyses: A case study of advanced Vehicle control and safety system, IEEE, SMC'99, TOKYO, Japan, 12 -15, October 1999, Volume 1V, pp 558- 563

17. Rumar, K. (1999). Road safety and benchmarking. In: Proceedings of the Paris Conference on Transport Benchmarking. November 1999, Paris

18. Hauer, E. On exposure and accident rate. Traffic Engineering +Control, 36(3), 1995, pp.134-138

19. Elvik R., Vaa T., The Handbook of Road safety Measures. Elsevier Science, Oxford 2004

20. White Paper.European transport Policy for 2010: time to decise, Brussels, 12 IX 2001

21. Wilde G. J. S., A Theory of Risk Homeostasis: Implications for Safety and Health. Risk Analysis 2 (1982), p. 209 - 225; see: Evans L., Risk Homeostasis Theory and Traffic Accident Data. Risk Analysis, Vol. 6, No. 1, 1986, pp. 81 - 94; Wilde G. J. S., Notes on the Interpretation of Traffic Accident Data and of Risk Homeostasis Theory: Reply to L. Evans 


\section{ZASADY AKCEPTOWALNOŚCI RYZYKA W TRANSPORCIE}

\section{Wstęp}

Zarządzanie bezpieczeństwem $\mathrm{w}$ transporcie, to zarządzanie przez cele, a więc rodzaj zarządzania systemowego. Cele zarządzania bezpieczeństwem w dowolnym systemie transportowym można zdefiniować według ,filozofii głębokiej obrony" (defence-in-depth-philosophy): 1. minimalizacja ryzyka wypadków (profilaktyka), 2. minimalizacja liczby wypadków (metody bezpieczeństwa aktywnego), 3. minimalizacja skutków wypadków (metody bezpieczeństwa pasywnego), 4. minimalizacja skutków katastrof transportowych (plany ewakuacji, zarządzanie kryzysowe).

Zarządzanie bezpieczeństwem $\mathrm{W}$ transporcie rozumiemy $\mathrm{w}$ sensie operacyjnym jako zarządzanie ryzykiem. Jest to podejście typu ex ante do problemu poprawy bezpieczeństwa. Bazuje bowiem na proaktywnej koncepcji „uprzedzenia”, unikania lub znaczącej redukcji przewidywanych skutków wypadków. Tymczasem tradycyjne podejście ex post, to reaktywna koncepcja wnioskowania na podstawie informacji powypadkowych.

\section{Ryzyko w transporcie}

W odniesieniu do transportu można mówić o ryzyku „wielowymiarowym”. Ma ono związek ze składnikami transportu (infrastruktura transportu, środki transportu, człowiek), ale także $\mathrm{z}$ realizacją łańcuchów dostaw i w tym sensie można mówić także o ryzyku logistycznym, [1]. Redukcję „wielowymiarowego" ryzyka transportu można osiagnać poprzez zarządzanie ryzykiem; ,measuring risk to manage it” - ten zwrot oddaje istotę zarządzania ryzykiem także $\mathrm{w}$ transporcie.

Zarzadzanie ryzykiem tworzą trzy obszary badania ryzyka: 1. analiza ryzyka (risk analysis) - identyfikacja zagrożeń i oszacowanie częstości ich pojawiania się oraz oszacowanie ryzyka; 2 . ocena ryzyka (risk evaluation) ustalenie akceptowanych poziomów ryzyka; 3. sterowanie ryzykiem (risk control) - osiaganie akceptowanego poziomu ryzyka przy istniejących ograniczeniach ekonomicznych i społecznych. Każdy $\mathrm{z}$ tych etapów zarządzania ryzykiem ma bogatą literaturę przedmiotu; zamieszczono ją w pracy, [2]. 
$\mathrm{Na}$ etapie oceny ryzyka sprawą zasadniczą jest wybór kryterium wartościowania ryzyka. Takie kryterium zawsze odnosi się do trudnego problemu społecznej akceptowalności ryzyka, [3].

Nie ma dotychczas kryteriów wartościowania ryzyka specyficznych dla systemów transportowych. Zastosowanie znajdują znane kryteria ogólne, których implementacją, a także kwantyfikacją (progi akceptacji ryzyka) - w odniesieniu do szeroko rozumianego transportu zajmujemy się w tym referacie.

\section{Wartościowanie i akceptacja ryzyka}

Problem wartościowania i akceptacji ryzyka jest uniwersalny, zarówno w wymiarze indywidualnym, jak również społecznym. Rozwój nowych technologii generuje nowe ryzyka, co może implikować nowe formy ich akceptacji. Akceptacja ryzyka musi mieć jakieś punkty odniesienia: najprościej jest odwołać się do nabytych doświadczeń oraz istniejących praw i norm. Ale nowe ryzyka dają nowe doświadczenia, co musi wpływać na zmianę praw i norm dotychczas obowiązujących, [4].

Poniżej trzy (jest więcej) praktyczne zasady akceptacji ryzyka, które można odnieść do transportu: 1. W przypadku pojawienia się ryzyka poważnych wypadków transportowych, dąży się do zachowania poziomu bezpieczeństwa nie gorszego niż w innych krajach; 1. „Ryzyko codzienne” nie powinno znacznie wzrastać na skutek udziału człowieka w działalności transportowej [np. udziału w ruchu drogowym]; 2. Przy planowaniu inwestycji transportowej należy przeprowadzić badania, czy istnieja alternatywy, dzięki którym uzyska się podobny efekt transportowy przy mniejszym ryzyku; 3. Środki dla poprawy bezpieczeństwa transportu powinny być lokowane tam, gdzie przynoszą najlepsze rezultaty.

Ze znanych w przemyśle ,zasad praktycznych” wartościowania ryzyka wymieńmy: 1. doświadczenie - wykorzystywane dla wartościowania ryzyka w powtarzalnych sytuacjach warunkach; 2 . normy - uznaje się ich wagę $\mathrm{w}$ każdej procedurze akceptacji ryzyka; 3 . głęboka obrona - zasada wedle której żaden środek bezpieczeństwa nie jest doskonały, wobec czego wymaga się stosowania kilku środków zabezpieczających (barier, warstw) dla każdego potencjalnego wypadku w analizowanym systemie techniki; 4. analiza ilościowa ryzyka - zasada podejścia operacyjnego do oceny ryzyka; 5. Risk Cost Benefit Analysis, (RCBA) - zasada uznająca „ryzyko” za kategorię ekonomiczną. 


\section{Kryteria wartościowania i akceptacji ryzyka. Implementacje dla transportu}

W ocenie ryzyka stosowane sa dwie podstawowe metody: 1. metoda porównawcza, 2. substitution method. W metodzie porównawczej porównuje się obliczone ryzyko ze znanym i akceptowanym ryzykiem indywidualnym i grupowym lub poziomem ryzyka zagrożeń naturalnych. Obszar ryzyka dzielony jest na trzy poziomy: 1. ryzyka akceptowalnego (ustalanego w ramach polityki bezpieczeństwa przez władze państwowe), 2. ryzyka tolerowanego, 3. ryzyka nieakceptowanego. Wyboru ryzyka dokonuje się pomiędzy: ryzykiem szeroko akceptowanym, a ryzykiem nieakceptowanym, które nie powinno być przekroczone (niezależnie od spodziewanych korzyści ekonomicznych lub społecznych). Między tymi dwoma ryzykami granicznymi jest „obszar ryzyka tolerowanego". I to właśnie w odniesieniu do „ryzyka tolerowanego” stosuje się różne kryteria (zasady) wyboru ryzyka.

ALARP (As Low As Reasonably Practicale) wprowadzona przez Health and Safety Executive, [5]. Zgodnie z tą zasadą - najlepszy jest wybór ryzyka „,tak niskiego, jak to jest praktycznie uzasadnione.

$\mathrm{W}$ odniesieniu do analizowanego fragmentu dowolnego systemu transportowego - interpretacja zasady ALARP byłaby następująca: stan techniczny środka transportu, element infrastruktury transportowej, proces roboczy (ruch) - są uważane na tyle bezpieczne, na ile obliczone dla nich ryzyko jest „tak niskie, jak to jest praktycznie uzasadnione”. Kontrola ryzyka polega na utrzymywaniu ryzyka resztowego na poziomie ryzyka akceptowanego, który to poziom może być wyznaczany metodami badania preferencji przy stosowaniu technik eksperckich, albo też wyznaczany przez RCBA, [6].

W większości europejskich krajów maksymalnie akceptowane indywidualne ryzyko wynosi $10^{-6}$ na rok, natomiast ryzyko grupowe $10^{-5}$ na rok lub nawet $10^{-4}$ na rok (Dania), [7].

Kryterium ALARP stosowane było między innymi $w$ transporcie kolejowym Wielkiej Brytanii oraz transporcie samochodowym i kolejowym w Szwajcarii. Na kolejach brytyjskich stosuje się następujące wartości kryterialne, [8]: 1. górna granica obszaru ALARP: ryzyko indywidualne pracowników kolei $10^{-3}$, pasażerów i publiczności $10^{-4}$ [zgonów / rok]; 2. dolna granica obszaru ALARP: ryzyko indywidualne pracowników, pasażerów i publiczności $10^{-6}$ [zgonów / rok]. Zasada ALARP znalazła też zastosowanie $\mathrm{W}$ zarządzaniu ryzykiem transportu morskiego. W 
szczególności wykorzystywana jest w metodologii Formal Safety Assessment, [9].

W Holandii obszar ryzyka tolerowanego jest dzielony na dwa obszary a ryzyko indywidualne ma być zredukowane do poziomu $10^{-6}$ na rok $\mathrm{w}$ tempie zależnym od postępu technicznego i technologicznego. Stosowana tutaj ogólna zasada ALARA (As Low As Reasonably Achievable), jest w pełni uzasadniona. Zasada ta była stosowana w transporcie drogowym, [10]. Jednym z głównych celów profilaktyki bezpieczeństwa transportu jest minimalizacja dodatkowego ryzyka społecznego (grupowego) będącego efektem eksploatacji systemów transportu; chodzi o to, aby nie przekraczało ono wartości bezwzględnej ryzyka podstawowego $R_{a g}$. Aby to zagwarantować należy wyznaczyć funkcję rozkładu średniorocznego ryzyka (Annual Mean Risk Distribution Function, AMRDF), która pokazuje na jakie ryzyko naraża się każda osoba badanej grupy, oraz które ryzyko jest większe, a które mniejsze od bezwzględnej wartości $R_{a g}$, [11]. Funkcja AMRDF może znaleźć zastosowanie w podejmowaniu decyzji, co do form transportu i wariantów trasy - w przewozach towarów niebezpiecznych, zarówno w transporcie drogowym, jak też transporcie kolejowym.

$\mathrm{Z}$ wielu znanych wskaźników akceptowalności ryzyka - w analizach ryzyka transportu zastosowanie mogą znaleźć m.innymi: wskaźnik śmiertelności wypadków (Fatal Accident Rate, FAR) oraz wskaźnik potencjalnej utraty życia (Potential Loss of Life, PLL).

Francuska zasada GAMAB - Globalement Au Moins Aussi Bon, lub w wersji angielskiej: Globally As Good As Exiting - jest wyrażana krótko: bezpieczeństwo porównywalne dla równoważnych systemów (safety is comparable to the equivalent system). Według tego kryterium nowy system transportowy nie może dawać ryzyka większego niż ryzyko technicznoeksploatacyjne istniejących równoważnych systemów transportu. Kryterium to jest nieprecyzyjne, podobnie jak ALARP., [12]. Powyższa zasada jest przedstawiana niekiedy w wersji GAME - Globalement Au Moins Equivalente. Mówi ona, że każda zmiana w systemie musi pozostawić go, co najmniej tak bezpiecznym jak poprzednio. Zasada ta wprowadza formalnie aktualny poziom bezpieczeństwa jako punkt odniesienia i czyni go kryterium absolutnym. Co najmniej trzy kraje Unii Europejskiej stosuja to kryterium do oceny ryzyka i wyznaczania celów w programach bezpieczeństwa transportu, [13].

A oto przykład wykorzystania GAMAB kryterium do analizy ryzyka nowej inwestycji w transporcie kolejowym, [14]. Chodzi o to, żeby proporcja śmiertelnych wypadków kolejowych w starym i nowym systemie była stała: 


$$
\frac{n_{C}}{r \times C}=\text { const }
$$

$n_{C}-$ liczba przyczyn przypadających na jedną kolizję w nowym systemie transportu,

$r$ - wskaźnik średniego zapełnienia pociągu,

$C$ - pojemność pociagu (liczba pasażerów na pociąg).

Niemiecka zasada MEM - Minimum Endogenous Mortality. Według tej zasady nowa technika wprowadzana „tu i teraz" nie może „znacząco" podnosić śmiertelności jakiejkolwiek grupy społecznej. Oznacza to, że nowa technika nie może powodować ryzyka, które skutkuje śmiertelnością większą niż ,śmiertelność odniesienia”, czyli naturalna śmiertelność notowana w grupie wiekowej 5- 15 lat. Punktem odniesienia może być tutaj zapisany w CENELEC pre-standard prEN 50126 - poziom śmiertelności rzędu $2 \times 10^{-4}$ do $10^{-5}$ osób na rok.

Kryterium MEM oznacza, że indywidualne dopuszczalne ryzyko śmierci powinno być mniejsze niż pewien ustalony limit. W przypadku gdy to ryzyko ulega wzrostowi wskutek powstania nowej instalacji technicznej (np. nowej inwestycji transportowej) dopuszczalne indywidualne ryzyko śmierci może zostać zmniejszone odwrotnie proporcjonalnie do liczby zagrożonych osób, Rys.1. Wydaje się, ze ten wskaźnik ryzyka może być wykorzystywany szczególnie $\mathrm{w}$ analizach ryzyka transportu towarów szczególnie niebezpiecznych.

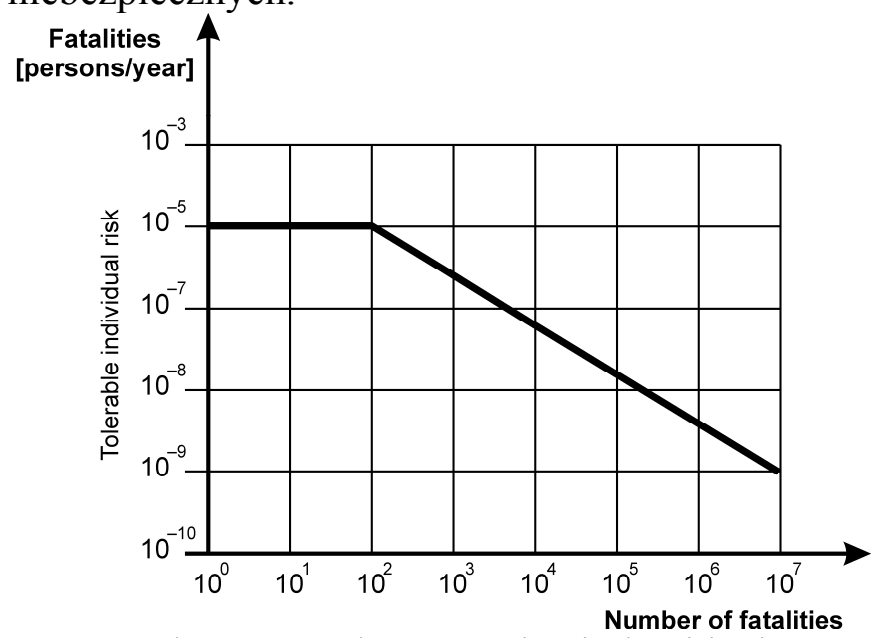

Rys. 1. Zasada MEM - dopuszczalne indywidualne ryzyko śmierci zależne od oczekiwanej liczby zgonów, [11, p. 427] 
Jako przykład zastosowania kryterium MEM do oceny ryzyka w transporcie kolejowym pokazujemy (dla kolei brytyjskich i niemieckich) tzw. tolerowany (akceptowany społecznie) poziom ryzyka $T$, który jest funkcją: 1. średniej liczby ofiar wypadków przypadających na jeden wypadek kolejowy, $C / A ; 2$. średniej liczby wypadków przypadających na statystyczna podróż, $A / J$; 3. rozkładu liczby wypadków kolejowych w czasie, $d A / d t ; 4$. czynnik zróżnicowania awersji do ryzyka (differential risk aversion factor), $f(C)$; 5. czynnik $b$ dopisujący korzyści systemu transportu kolejowego. Wówczas tolerowalność $T$ ryzyka można zdefiniować następująco, [9]:

Ponieważ wysoki poziom $T$ odpowiada niskiemu poziomowi ryzyka $r$ (i vice versa) możemy umownie zapisać formulę akceptowanego poziomu ryzyka transportu kolejowego; ta formuła może być przeniesiona $\mathrm{z}$ transportu kolejowego na inną formę transportu. Wtedy konieczna jest inna interpretacja terminu "podróż".

$$
r=\frac{1}{T}=\frac{\frac{C}{J} \times \frac{d A}{d t} \times f(C)}{b}
$$

\section{Problemy wartościowania ryzyka w ruchu drogowym}

Do oceny indywidualnego ryzyka śmierci w ruchu drogowym próbowano wykorzystywać kryterium MEM; obliczony wskaźnik $10^{-4}$ na [osobę/rok] bazował na następujących danych: 1. całkowitej liczbie wypadków w ciągu roku; 2. całkowitej liczbie pojazdów w ruchu; 3. średniej rocznej mobilności, tj. średniej rocznej liczbie przejechanych kilometrów, [15].

W zestawieniu z kryteriami MEM, czyli $2 \times 10^{-4}$ [zgony/osoba/rok], jest to podobny poziom ryzyka; a przypomnijmy, że kryterium MEM dotyczy śmiertelności $\mathrm{w}$ grupie wiekowej 5 - 15 lat i zakłada, że człowiek jest narażony na działanie około 20 różnych instalacji technologicznych. Ryzyko określane przez MEM jako akceptowalne jest na poziomie $10^{-6}$ na [osobe//rok], czyli $10^{-10}$ na [osobę/godz.] Gdyby odnieść ten wskaźnik do pojedynczego vehicle, to wyniósłby on $10^{-7}$ na pojazd.

Zasady GAMAB, ALARP i MEM były stosowane w tworzeniu metodologii oceny bezpieczeństwa systemów stosowanych do unikania zderzeń w ruchu samochodów, czyli systemów AVCSS (Advanced Vehicle Control and Safety Systems), [16].

$\mathrm{W}$ analizach ryzyka drogowego stosuje się również formułę:PR $=\mathrm{M} \times \mathrm{TR}$ gdzie: PR - ryzyko osobiste - ryzyko śmierci w wypadku drogowym odniesione do liczby uczestników ruchu drogowego; M - motoryzacjaliczba samochodów; TR - ryzyko ruchu drogowego - ryzyko śmierci w 
wypadku drogowym odniesione do jakiejś miary ekspozycji ryzyka, np. liczby pojazdo-kilometrów

Podstawowy model kwantyfikacji bezpieczeństwa w ruchu drogowym jest następujący, [17]:

$$
\mathrm{I}=\mathrm{E} \times \mathrm{A} / \mathrm{E} \times \mathrm{I} / \mathrm{A}
$$

gdzie: I - liczba rannych; $\mathrm{E}$ - ekspozycja ryzyka; A/E prawdopodobieństwo wypadku (accident risk); I/A - prawdopodobieństwo zranienia w wypadku (injury risk).

Powyższy model implikuje środki poprawy bezpieczeństw: wszystkie powinny minimalizować parametry: A/E, E oraz I/A.

A oto ilustracja wpływu parametru E ryzyka na poziom ryzyka śmiertelnych wypadków transportowych.

Tab. 1. Ryzyko śmierci w różnych gałęziach transportu w Enii Uuropejskiej. Źródło: ETSC (1999)

\begin{tabular}{|c|c|c|}
\hline & $10^{8}$ osobo-km & $10^{8}$ osobo-godz. \\
\hline droga & 1.1 & 3.3 \\
\hline kolej & 0.04 & 2 \\
\hline prom & 0.33 & 10.5 \\
\hline samolot & 0.08 & 36.5 \\
\hline
\end{tabular}

Warto tutaj wpomnieć, że liczba wypadków drogowych jest rosnącą funkcją ekspozycji E. Funkcja taka zyskała w literaturze przedmiotu nazwę funkcji bezpieczeństwa (Safety Performance Function, SPF), [18]. Najczęściej parametr E jest wyrażany jako natężenie ruchu drogowego lub jako liczba przejechanych kilometrów. Trzeba powiedzieć, że SPF jest najczęściej nieliniowa. Poniższy rysunek pokazuje przykładowy kształt funkcji SPF dla określonej drogi.

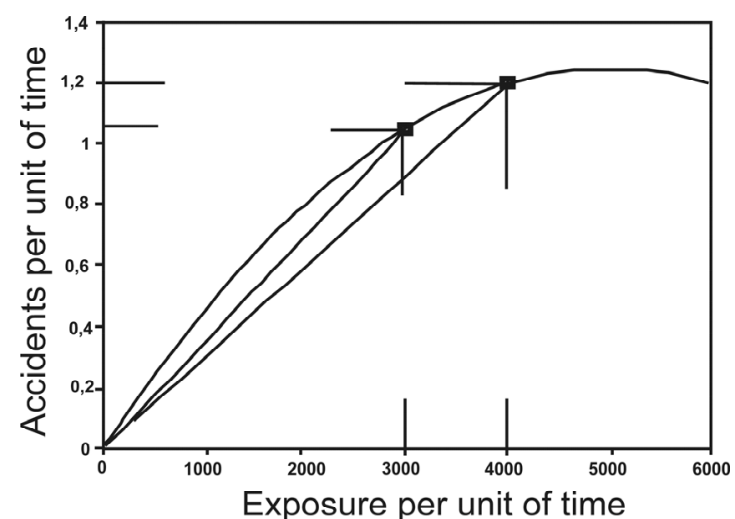

Rys. 2. Funkcja bezpieczeństwa i wskaźnikwypadków, [18] 
Odnotujmy jeszcze inny wskaźnik ryzyka w ruchu drogowym. Jest on prosto definiowany poprzez relację pomiędzy ryzykiem utraty zdrowia(health risk) i ryzykiem w ruchu drogowym (traffic risk), [19]:

$$
\mathrm{HR}=\mathrm{TR} \times \mathrm{MR}
$$

HR - health risk (zabici na 100.000 mieszkańców)

TR - ryzyko $w$ ruchu drogowym (zabici na 100.000 pojazdów samochodowych)

MR - wskaźnik ryzyka motoryzacyjnego [motorisation risk] (liczba pojazdów na liczbę mieszkańców kraju).

Table 3. Wartości HR oraz TR dla kilku krajów

Source: WHO Regional Office for Europe, Copenhagen 2005

\begin{tabular}{|l|c|c|}
\hline \multicolumn{1}{|c|}{ kraj } & HR & TR \\
\hline Polska & 16.3 & 44.6 \\
\hline Wielka Brytania & 6.0 & 12.1 \\
\hline USA & 15.2 & 19.3 \\
\hline Całkowity (IRTAD) & 12.2 & 20.6 \\
\hline
\end{tabular}

A oto oszacowania Europejskiego Wskaźnika Śmiertelności w Ruchu Drogowym (European Road Safety Mortality Rate, ERSMR) wynikające ze statystyk wypadków drogowych z lat $2000-2005$ :

$\operatorname{ERSMR}=40.000 / 375 \times 10^{6}=1.07 \times 10^{-4}\left[\frac{1}{r o k}\right]$;

$\operatorname{ERSMR}_{\mathrm{TF}}=5 \times 10^{-6}\left[\frac{1}{r o k}\right] ; \mathrm{ERSMR}_{\mathrm{HF}}=1 \times 10^{-4}\left[\frac{1}{\text { rok }}\right] ;$

gdzie: ERSMR $_{\mathrm{TF}}=$ ERSMR dla niepowodzeń technicznych (technical failure); $\mathrm{ERSMR}_{\mathrm{HF}}=\mathrm{ERSMR}$ dla niepowodzeń czynnika ludzkiego (human failure).

Używając znanych kryteriów wartościowania ryzyka i przyjmując zakładany przez Komisję Europejską poziom 20.000 zabitych na drogach w 2010 roku, [20] - można wyznaczyć:

Akceptowany Europejski Wskaźnik Śmiertelności Drogowej $=5.3 \times 10^{-5}\left[\frac{1}{r o k}\right]$. gdzie: $5.3 \times 10-5\left[\frac{1}{\text { rok }}\right]=20.000 / 375 \times 10^{6}$; tutaj liczba $375.000 .000-$ to liczba kierujących pojazdami samochodowymi na obszarze Unii Europejskiej. Tak więc wartość $5.3 \times 10^{-5}\left[\frac{1}{r o k}\right]$ można uznać jako poziom tolerowanego ryzyka drogowego w UE w horyzoncie roku 2010. 
Teoria Homeostazy Ryzyka (Risk Homeostasis Theory, RHT). Według koncepcji RHT zachowanie każdego uczestnika ruchu drogowego w określonych sytuacjach ruchowo-drogowych jest adekwatne do „do akceptowanego poziomu ryzyka", to znaczy jest wypadkową pomiędzy ryzykiem akceptowanym (subiektywnym), a ryzykiem rzeczywistym (obiektywnym). W RHT definiuje się straty w wypadku jako iloczyn częstości wypadków i ich kosztów. Stąd wynika, że zmiana poziomu bezpieczeństwa zależy od obiektywnego prawdopodobieństwa wypadku i od szacowanych kosztów wypadku. Może być zatem tak, że poprawa brd może być rezultatem redukcji kosztów wypadku, pomimo, że obiektywne prawdopodobieństwo wypadku pozostaje niezmienne. Algebraiczna formuła RHT teorii jest następująca: $F=T \times R$. Liczba zabitych $F$ jest wprost proporcjonalna do łącznego czasu $\mathrm{T}$ uczestnictwa $\mathrm{w}$ ruchu drogowym i do statystycznego średniego poziomu $\mathrm{R}$ ryzyka akceptowanego przez uczestników ruchu drogowego. Formuła jest stosowana dla wybranego obszaru sieci drogowej; chodzi bowiem o oszacowanie liczby P uczestników ruchu drogowego.

\section{Podsumowanie}

Jaki jest zatem dopuszczalny poziom ryzyka? Odpowiedź jednoznaczna jest niemożliwa. Każdy poziom ryzyka inny niż zero jest arbitralny i sporny. Poza tym: mówiąc o dopuszczalnym poziomie ryzyka powinno się rozróżnić pomiędzy różnymi rodzajami ryzyka; indywidualnego, społecznego, dobrowolnego etc. Jaki poziom ryzyka jest dopuszczalny dla indywidualnego użytkownika transportu, gdy ten jest w podróży do określonego celu i określonym środkiem transportu? Jakie jest dopuszczalne ryzyko dla społeczeństwa jako całości, innymi słowy jak wiele wypadków lub rannych osób w skali roku - społeczeństwo jest w stanie zaakceptować w systemach transportu? To są pytania podstawowe. Jest ich więcej. Problem wartościowania ryzyka w różnych systemach transportu jest tutaj problemem kluczowym.

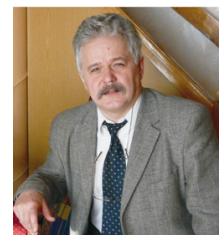

Fot. dr inż. SZYMANEK Andrzej, Politechnika Radomska. Wydział Transportu. Specjalność naukowa: modelowanie matematyczne bezpieczeństwa $\mathrm{w}$ transporcie. 